\title{
A decolonial reading of the 1840 English-Setswana Gospel of Luke with specific reference to Luke 1:59 and Luke 2:21 from the perspective of the damnés
}

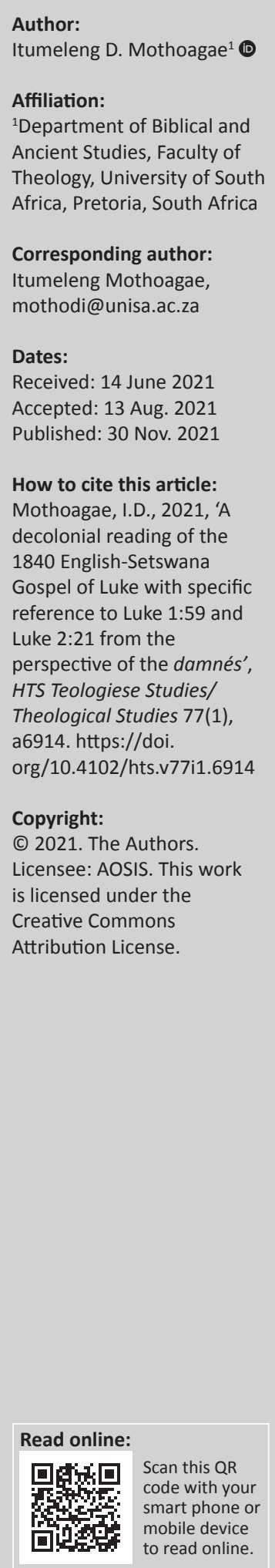

In their missionary endeavour the missionary societies such as London Missionary Society, did not only engage in public preaching but their public preaching took the form of a biblical discourse. They engaged with their audiences in a dialectical manner with the aim of converting them. In order to do that they had to question the religio-cultural practices of their audiences. The practices that the audiences engaged in were either public or private. This article analyses the public discourse about male and female initiations that took place in the public spaces and found their way into a newspaper named Mahoko a Becwana. The biblical discourse was amongst the missionaries: the converted and the traditional Batswana. It also focuses on Luke 1:59 and Luke 2:21 as translated by Robert Moffat. It is argued that the symbol thupiso is transmuted into bogwera. It is further argued that in his translation he engages in biblical discourse thus distorting the cultural meaning.

Contribution: The article contributes to the biblical discourse within biblical sciences scholarship. It aims to contribute to the continual debates on the excavating and levelling of the epistemological voices that have been suppressed through colonial epistemological universalisation of knowledge from the perspective of the damnés.

Keywords: bogwera; damnés; thupiso; circumcision; biblical discourse; ngwao; decoloniality.

\section{Introduction}

This article analyses the identified sections of the 1840 English-Setswana Gospel of Luke, namely Luke 1:59 and 2:21. In analysing these texts, the fundamental question that is being addressed is how a foreign concept is interpreted and its meaning is derived from the cultural reference of the receptor culture. A decolonial analysis is applied from the social and epistemic location of the subaltern (damnes). ${ }^{1}$ The reader is located within the context of the subaltern group (motswana), with the aim of bringing forth the suppressed and marginalised geo- and body politic of knowledge of the Batswana.

In this article I will focus on both the symbol and meaning of circumcision within the religiocultural perspectives as described in the biblical text and that of the Batswana. From the perspective of the biblical text the religio-cultural practices (or in Foucauldian terms 'discursive practices') of circumcision and functioned as a marker, embodiment and a symbol of the religio-cultural belief system containing both cultural meaning and significance. Biblically the symbol of circumcision functioned as both an entry into an elected nation as well as a covenant between the Israelite God. In the Old Testament, the Jewish circumcision embodies this culturally significant symbolism. While in the case of the Batswana, this symbol functioned as entry into manhood and it involved an intense training through passing on of cultural norms and knowledge through orality. However, this cultural practice of bogwera was one of the cultural practices that did not find favour with the missionaries.

Both of these symbols have to be understood within their own social and epistemic locations. Through public discourses the missionaries engaged with the Batswana from the perspective of perceiving and viewing such a practice as an expression of heathenism and a hindrance to conversion, civilisation and colonisation. The letters to Mahoko a Becwana illustrate these discourses

1.The concept of damnes is borrowed from Fanon's (1968) book The Wretched of the Earth. The concept is a French word meaning damned. The concepts in this article are applied in a similar manner that Fanon applies it. In other words, the analysis in this article is carried out from the perspective of a motswana whose traditional practices and indigenous knowledge system were deemed to be heathenism and uncivilised. 
even amongst the missionaries and the Batswana. As I will show in this article, for the Batswana their rite of initiation is imbued with deep cultural significance, hence it has various stages each with its own symbolism. I will argue in this article that it is this cultural significance and symbolism that caused the tension between the two concepts that flowed from the 1840 Setswana translation from the English.

\section{Moffat's translation of the Gospel Luke}

The following section focuses on Moffat's translation of the Gospel of Luke with reference to Luke 1:59 and 2:21. These texts are selected for an analysis of the concept of circumcision as translated in Moffat's translation (Table 1).

\section{The covenant of circumcision}

In the two given passages the notion of circumcision is first used in relation to John the Baptist and secondly in relation to Jesus. Both texts refer to the Mosaic law and circumcision as a covenantal requirement that each Jewish son has to undergo. In terms of the Jewish ritual circumcision ( $B^{\prime}$ rit Milah) this ritual is symbolised by the removal of the foreskin of the penis. This ritual emanates from the understanding that it was a commandment given to Abraham in the Torah that all his descendants and their slaves must be circumcised (Gn 17:7-14; Lv 12:3).

The meaning and symbolism of the ritual indicates its twodimensional nature, namely that it has to do with identity and religion. It is through the performance of this ritual that the male child gets formally incorporated into the Jewish people. Religiously, the rite signifies a covenant of circumcision whereby the parents obtain a triple blessing for the child, namely a life blessed by the Torah, the wedding covering/tent and noble deeds (Cohen 2003:30-43). The question then arises: who performed the act of circumcision? In the book of Genesis, the narrator depicts Abraham as the person who performed the circumcision on both his sons. Cohen (2003:30-43) argued that in terms of the Jewish law, it was the father or his representative who performed the act of circumcision. In other words, the father was responsible for circumcising his own male child. He further maintains that over the years the rite developed as an institution, and it is within this institution that circumcision was performed by

TABLE 1: Inter-textual comparison between the Byzantine text, 1611 King James Bible and the 1840 New Testament translation by Moffat.

\begin{tabular}{|c|c|c|}
\hline Byzantine text & 1611 King James version & $\begin{array}{l}1840 \text { New Testament } \\
\text { translation by Moffat }\end{array}$ \\
\hline 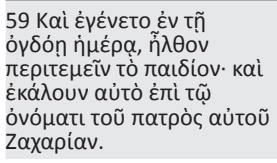 & $\begin{array}{l}59 \text { And it came to pass, } \\
\text { that on the eighth day } \\
\text { they came to circumcise } \\
\text { the child; and they called } \\
\text { him Zacharias, after the } \\
\text { name of his father. }\end{array}$ & $\begin{array}{l}59 \text { Mi ga rihala, ka bat la } \\
\text { go guérisa ñuanyana ka } \\
\text { motsi oa éit, ba mitsa } \\
\text { Sakaria, yaka leina ya } \\
\text { rague. }\end{array}$ \\
\hline 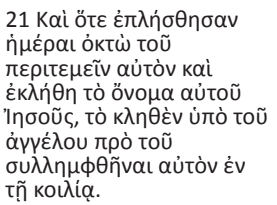 & $\begin{array}{l}21 \text { And when } 8 \text { days were } \\
\text { accomplished for the } \\
\text { circumcising of the child, } \\
\text { his name was called } \\
\text { JESUS, which was so } \\
\text { named of the angel before } \\
\text { he was conceived in the } \\
\text { womb. }\end{array}$ & $\begin{array}{l}21 \text { Mme metsi e éit e sina } \\
\text { bohéta, e ba isañ nuana } \\
\text { boguéra ke eona, eabo } \\
\text { leina ya gague le birioa } \\
\text { YESU, ye le biricoeñ ke } \\
\text { moengeli a e si a ithualoe } \\
\text { mo sepopéloñ. }\end{array}$ \\
\hline
\end{tabular}

the mohel. According to him the mohel is someone trained to perform the ceremonial rites of $b^{\prime}$ rit milah (circumcision), thus emerging as professionally representing the community fathers (Cohen 2003:39).

It is in the rite of $b^{\prime}$ rit milah that its symbolism, meaning and the significance becomes apparent. The symbolism also points to the cultural and religious identity represented by the rite. Reflecting on the circumcision of John the Baptist and Jesus and linking it with the covenantal symbol, Pao and Schnabel (2007) make the following argument:

In light of the significance of circumcision as a sign of the Abrahamic covenant, it is tempting to see John's and Jesus' reception of name during the rite of circumcision as an attempt to make connections between Abraham and the fulfilment of the Abrahamic promises. The Lukan use of the expression 'covenant of circumcision' (Acts 7:8) may lend support to this reading. This verse does not, however, explicitly affirm that the naming of the child on the eighth day was the widely accepted practice of the first century Palestinian Jews. (p. 263)

Similarly, Marshall (1978:88) argued that in the text there is an intended parallelism between the two infants (John and Jesus). He stated that the circumcision rite as described by Cohen was performed by the head of the household. He goes further than Cohen, however, maintaining that women too could perform circumcisions (1 Mac. 1:60). Marshall (1978:88) stated that amongst those invited to the ceremony would be neighbours and relatives (cf. Ru. 4:17), thus comparing the circumcision rite to a ceremony of christening. He stated:

What is unusual is the association of name-giving with circumcision, which is otherwise unattested in contemporary Judaism. The earliest Jewish example of name-giving in connection with circumcision dates from the eighth century. (Marshall 1978:88)

Reflecting on Luke 2:21 Marshall (1987:114) argued that the text refers to the circumcision and naming of Jesus. In other words, 'the child is duly circumcised, named and presented to God'. Based on the observation by Marshall it can be argued that the naming occurs as a consequence of circumcision. Circumcision as a sign signifies an entry into a tribe; it is a sign of belonging, an identity marker. It also functions as an embodiment of a certain religious and cultural outlook of a people based on the Mosaic Law (Karris 1990:683).

\section{The foreignisation of bogwera as the theo-politic of knowledge and the geo-politic of knowledge}

The symbolism and the meaning of the rite of circumcision in Moffat's translation have to be located within its cultural context. Circumcision as a sign and symbol gets imported into this cultural context, which gives rise to its completely different understanding. It is within this cultural location that the rite is understood and finds its meaning. In translating the rite of initiation as a Judaeo symbol of circumcision the translator imported a foreign concept while at the same time foreignising the indigenous concept with its specific symbols and meaning. In doing so, the translator not only ignored its social and 
epistemic location embedded in ngwao (it is an embodiment of the belief and knowledge system of the Batswana) by translating and conceptualising it within a foreign social and epistemic location he morphed the sign into a new symbol and gave it a new meaning. In order to do that, he first had to delegitimise it as a cultural sign. The delegitimisation of the bogwera also emanated from his views of the rite. Moffat (1842) stated:

Of their customs they are as tenacious as the Hindoo could be of his caste, that dreadful barrier to evangelization in the East Indies. Their youth, for instance, would forfeit anything rather than go uncircumcised [emphasis added]. This national ceremony is performed from the age of eight to fourteen, and even to manhood, though the children born previous to their parents being initiated cannot be heirs to regal power. There is much feasting and dancing on the occasion, and every heart is elated at these festivities. The females have also their boyali at the same age, in which they are under the tuition of matrons, and initiated into all the duties of wives, in which it merits notice, that passive obedience is especially inculcated. After these tedious ceremonies are over, the youth appears lubricated, assuming the character, and wearing the dress of a man, while he is considered able to bear the shield and wield the javelin. The girls also, when they have gone the round of weeks, drilling, dancing, singing, and listening to the precepts of the grave old women, have a piece of iron rather hot put into their hands, which they must hold fast for a time, though painful, to show that their hands are hard and strong for labour. They are then anointed, and, having put on the usual female dress, the lower part of their hair is shaven off, and the upper part profusely bedaubed with a paste of butter and sebilo, black shining ochre. Raised thus from comparative infancy to what they consider womanhood, they view themselves with as much complacency as if they were enrobed in the attire of the daughters of an eastern potentate. They have reached nearly to a climax in their life, for they expect soon to be married, and to be a mother they consider the chief end of a woman's existence. These ceremonies were prodigious barriers to the Gospel [emphasis added]. (pp. 172-173)

In the above citation, Moffat described the ritual according to his perception of the signs of manhood and womanhood. Furthermore, he reduced the rites to the cutting of the foreskin when it came to men. He further located the rite of bogwera into the equivalence of a Western understanding of circumcision or a Judaeo-Christian understanding. In doing so, he alienated the embodiment of ngwao expressed in these rites. He concluded that these ceremonies were barriers to the gospel. Could it be then that his use of the sign in his translation was because of a lack of knowledge about the significance of the sign in the cultural practices of the Batswana? Or perhaps he had no translational equivalent to circumcision? Could it be that he just did not have time for the cultural heritage of the Batswana? Why did he have such disregard and contempt for that which had cultural significance for them? One thing that is evident is that the given citation suggests that he probably knew more about the rite. If that is the case, did he not know that his use of such a word in his translation carried with it cultural significance? The foreignisation of bogwera not only alters the sign or the symbolism but also its sacredness, spiritual dimension the sacred, spiritual and religious dimensions are also marginalised in the process. Smith (1925) also referred to the rite where he stated:
Boys and girls underwent at puberty certain rites of initiation before they could be admitted as members of the tribe. In the case of boys, circumcision was practised, and in such a barbarous manner that many of them died of the operation. The ordeals through which the young people passed were of great severity, the beatings and exposure to cold all being intended as a preparatory discipline. They were taught various matters pertaining to their future life in the community: many things of a very objectionable character. The missionaries discountenanced these ceremonies on account of the filthy practices and songs which formed part of them. (p. 100)

The categorisation of bogwera as barbaric was typical of the European viewpoint. His explanation of bogwera reflects a problematic representation of the rite. The rite of initiation (bogwera) did not function in a similar fashion like Israelite circumcision. For the Batswana it was not an initiation into a community, rather it was passage to manhood. The use of the term 'filthy' denotes a form of surveillance and power. It also creates a dichotomy between that which is characterised as good, clean and pure and that which can be viewed as the opposite. The problem is that Smith, like Moffat, does not contrast the rite with anything in the West, this is because there is nothing to compare it with. Perhaps the idea to classify the rite as filthy could be as a result of the various symbols that were used during the rite. Could it be because they themselves did not know the symbolism surrounding the rite? The notion of labelling the rite as 'filthy' somehow functions as a precursor to distinguish between that which has cultural significance, its symbolism and meaning versus the lack thereof in understanding what is behind the ritual. Subsequently, it leads to the rite being labelled as heathenism and uncivilised. The epistemological paradigm that delineates something to be either good or evil gives rise to the normativity and universalisation of the dichotomisation of goodness and evil. It is in translating the cultural, sacred and religious ritual that the translator marginalises the symbol and meaning amplified through the spiritual aspect of the rite. The spiritual aspect of the rite is the role of the diviner-healer and the belief in the presence of both communal and respective family ancestors.

It was the view of Robert Moffat that public rituals such as these ought to be substituted with 'civilised' lifestyle. In relation to bogwera, I would contend that there was a political aspect to the practice. The divine-healers infuriated the missionaries and they were central in most of the public rituals. Mothoagae (2017) stated:

At the centre of this is the belief in the ancestors as the protectors and providers of the community. The spiritual aspect of the community is expressed in the understanding of the divine as being hierarchically ordered. Mogapi explains the belief system of Batswana by pointing out that there is a hierarchy within the divine. (p. 3)

It is essential to comprehend how biblical discourse and debate/persuasion functioned in the exercise of foreignising and re-domesticating the practice of bogwera with the intention to colonise and Christianise the people. The missionaries' opposition of such practices causes one to 
question their understanding of the religious, political and economic aspects of the rite of initiation. It further requires reflection on the notion of colonial power and knowledge production in producing subjects. It is evident in the missionaries' letters, journals, autobiographies and memoirs that they were not completely ignorant but had some knowledge of the rites. While someone like Moffat thought he was exposed to the rites, he remained ignorant of their religious significance. Moffat and Moffat (in ed. Schapera 1951) referred to Moffat as someone who is amazingly devout and energetic. In essence he was evangelist who held that the primary task of a missionary was 'to teach poor heathen to know the Saviour'. He believed that engaging in traditional customs and in political pursuits was irrelevant. On the contrary, for example, the activities of a missionary, John Philip represented the oppressed Cape natives. This is inductive of his disposition regarding the traditional cultural beliefs. Moffat and Moffat (in ed. Schapera 1951) made the observation on Moffat's stance towards ngwao of Batswana:

He was apparently interested in the BaTlhaping, not as people with lives of their own, but merely as souls to be saved. Throughout he insists upon their degenerate character; over and over again he refers to them bitterly as liars, beggars, and thieves. Other contemporary writers (Butchell, for instance) had an equally low opinion of the people, but that no obstacle to recording what could be learned about their culture. To Moffat, however, the traditional usages of the BaTlhaping were only a hindrance, at times a powerful hindrance, to acceptance of the Gospel; and usually, when he deigned to comment upon them at all, it was merely in order to show what a sordid contrast they were to the dignified observances of a Christian life. (p. xxvi)

As Bassnett and Trivedi (1999) reminded us, translation does not occur in isolation, but forms an element of an 'ongoing process of intercultural transfer' that is determined by an unequal relationship between authors, systems and texts. The adoption of the bogwera symbolism and meaning thereof did not take place in vacuum. The translator also located and placed the practitioners of the rite at margin, removing them at the centre. A space they occupied as the custodians of the ritual. He did this by reducing the bogwera rite (initiation) as an act of removing the foreskin, he separated it from its traditional meaning, which became a symbol of Abrahamic covenant, a symbol of nation identity, as well as a symbol that is orientated towards an expression of patriarchy. As stated earlier in Luke 1:59 and 2:21 the rite is to be understood within its cultural context with its specific symbolism and meaning. Thus, it can be argued that the manner in which the two texts were translated was with some sense of the Jewish tradition and that of the receptor culture. The argument advanced by Bassnett and Trivedi that translation does not occur independently is relevant here; the Setswana translation was carried out within social, economic, political and religious realm of the Batswana. Following Venuti's argument, translation then is an exercise of power, which resides in the employment of language as an ideological tool of exclusion or inclusion of the reader, a value system, belief system (Venuti 1995:122). I submit that the transmogrification of the practice of bogwera as the cutting of the foreskin (circumcision) outside of its religio-cultural conceptualisation as a rite signifying someone entering the developmental stage of manhood, was actually a process of alienation and rewriting of the cultural symbol. This is illustrated by a letter written by Tshikedi Mosegedi (in Words of Batswana: Mahoko a Becwana, October 1891). The letter reads as follows (Mgadla \& Volz 2006):

30 August, 1891

To the Editor,

I am answering the words from the month of April. Doesn't it seem like people are more afraid of light than darkness? John says that light shines in the darkness, but the darkness does not overcome it (Joh.1:5). This practice of initiation causes me pain. I hear that children who had been taught in school have gone back to the vomit. They now tumble in the mud, especially the son of Mankurwane and the son of Molale. This practice of initiation is still hurting me, and even today I dislike initiation rites with all my heart. I say God should strengthen the heart of the Government to stop initiation rites immediately. (pp. 229-230)

The given citation indicates how biblical discourse infiltrated into the cultural belief of the Batswana at that time. Furthermore, the letter illustrates the tensions that were occurring between the so-called heathens and Christians. It is in the letter that we can explicitly ascertain the categorisation of the ritual as belonging to the realm of darkness. Thus, the Setswana concept of the rite of initiation has been used in the translated text. Not only did it further isolate the concept from its cultural significance but it also became a biblical tool to engage in biblical discourse.

\section{Re-domestication of bogwera in Luke 1:59 and Luke 2:21: Tensions between the source text and the indigenous image, symbol and meaning}

In the given sections I outlined the Jewish tradition of circumcision, its meaning and symbolism and the Setswana ritual of initiation. It is apparent that both rituals have different symbolism and meanings. It is also evident that both these rituals are not only distinct in themselves but the manner in which they are transmitted raises all kinds of possible translational tensions and issues of equivalence. They also point to the politics of interpretation that took place at the time of translation and the inequality between the source text and the receptor culture emulated in the power dynamics expressed in the linguistic and cultural knowledges.

Based on the given argument we can palpably observe the politics of interpretation in the way the translator interpreted the sign bogwera. Based on his ignorance and disregard of the religio-cultural practices of the receptor culture, Moffat translated bogwera as circumcision negating its cultural significance. In so doing, he re-domesticates the sign bogwera thus giving it a new meaning and symbolism contrary to its cultural meaning and symbolism. As indicated in the 
previous section dealing with the Jewish symbolism, conceptualisation and meaning of circumcision and the Setswana rite of initiation it is apparent that both these symbols embody a different meaning. In translating the circumcisions of John and Jesus in the manner in which he did, it can be argued that the translator altered the Setswana symbol, which had its own cultural meaning and morphed it to signify a Jewish cultural symbol of an entry into a tribe, a covenantal sign of a chosen race.

In the process of re-domesticating bogwera, Moffat excluded another aspect of the rite, which is the secrecy that accompanied it, namely the location and the processes of initiation. A particular mystery is retained within the realm of this rite, which is not the case with the Judaic ritual, which was a public event that took place at the temple. Lastly, through an act of re-domestication, Moffat excluded yet another component of the rite, namely the mediators of conventional knowledge. In the case of the Judaic rite, circumcision took place in front of a priest, accompanied by conventionalities. It neither had the educational and didactic circumference of bogwera, which accompanied an entry into manhood, nor did it entrench a cultural hierarchy in which particular mediating roles had been allocated to members of a particular community.

The re-domesticating of bogwera as circumcision was a performance of epistemic privilege that the translator displayed with regard to the cultural phenomenon surrounding such a rite. In doing so, Moffat did not only redomesticate bogwera as the rite to entry into a religiocultural identification of a nation. It was also an act of interpretation that led the distortion of the rite wittingly or unwittingly. Such a distortion not only affects the politics of knowledge production, interpretation and the pervasive inequalities around the source text and the receptor culture but it also functions as a form of politics of erasure. The circumcision of John and Jesus then becomes a frame of reference in interpreting and giving meaning to the Setswana rite of initiation. The reader's frame of reference becomes that which is culturally practiced. It is at this interpretative level that the Setswana rite, symbolism and meaning were reduced to an act of circumcision (go rupa). The name of the rite or the entire rite became an inference and derived its new meaning from the circumcision of John and Jesus, thus leading to the alienation of the symbol embedded within the cultural indigenous knowledge system of the Batswana. Moffat did this by not distinguishing between bogwera and thupiso (circumcision). The following questions then arise: If the Batswana drew a distinction between bogwera and thupiso, then why did Moffat in his translation not draw the distinction? Why didn't he use thupiso (rupa) as an equivalence to circumcision? The use of the name thupiso (rupa) as an equivalence to Jewish circumcision partially addresses the translational alternatives at the same time it could be argued that the use of the term thupiso (rupa) is not without problems of its own. Could it be that he did not know that the Batswana had a word for circumcision? It is in not providing an equivalence to the source text that the translator not only alienate its symbol, he at the same time re-ordered the spiritual and cosmological spaces associated with the rite. The re-domestication of bogwera as implying circumcision rather than using an alternative concept, thupiso, was a performance of altering of the meaning, illustrating the dehumanisation of a non-European culture and tradition.

I would hypothesise that to a 19th century Motswana reader, the text expressed contradictions between his or her religiocultural beliefs and the biblical text. Firstly (in v. 21), the circumcision of Jesus took place on the eighth day. He was an infant, whereas for a Motswana, bogwera took place when a boy was entering adulthood (as a young adult). Secondly, not only was Jesus circumcised but he was also given a name. The rite of initiation, on the other hand, was preceded by the naming rite, which took place around the time when the child would be 3 months old. Such an event would be presided over by the father, located at the homestead ( $k g o t l a)$. Thirdly, the text became a method to transfer JudaeoChristian tradition by means of the Western colonial Christian worldview, serving as discursive mode denigrate ngwao ya Batswana, thus questioning the relevance of the indigenous knowledge system of the Batswana. Judaeo-Christian religion substituted the rite of initiation as a spiritual space. The act of foreignisation and re-domestication of bogwera had a culturespecific function, that is, to transfer imperialist cultural memory and standards contained in the source text into the receptor culture, thus performing into the mind of the Batswana readership epistemic violence and spiritual epistemicide.

It is for that reason that I would argue that for the Batswana the interpretation of the symbol outside of its cultural link must have presented them with a paradox. This is because, as I have previously argued, the text was read drawing inferences from cultural experiences. Thus, not only was the symbol foreign but it was also morphed into a new symbol. By translating circumcision as a representation of bogwera, the symbolism of bogwera no longer carried with it the connotation of an entry into manhood, but rather, it was biblically installed as another occupant, implanted in the original spiritual spaces of the Batswana. Through his use of the word bogwera, Moffat used the word bogwera to engage in intercultural transfer. The text then became a means to suppress the indigenous knowledge system.

The act of foreignisation and re-domestication was an act of demonisation and colonisation of the spiritual spaces of the Batswana. It is in analysing the healing and exorcism narratives in the 1840 English-Setswana Gospel of Luke that we are confronted with translation as an act of rewriting in the form of foreignisation and re-domestication. It is in reading these texts from a cultural hermeneutics perspective that the culture of the first readers of the translated text has more influence on how the biblical texts are to be understood, how the missionaries used them in African communities and how it altered the cultural landscape of those for whom 
the text was translated. Put differently, cultural hermeneutics enables us to identify, for example, that the King James Bible was translated for a particular audience, namely the British.

As a text, the 1611 King James Bible influenced and helped to construct the British identity and culture and even impacted the English language. The culture of its first readers was unequivocally British. In analysing the 1840 English-Setswana Gospel of Luke, it is essential that the British culture and identity be taken into consideration as it is through its cultural lenses that the 1840 EnglishSetswana Gospel of Luke and subsequently the 1857 English-Setswana Bible are to be analysed and understood. The missionaries sought to domesticate this culture in order to alter and replace the religio-cultural practices of the Batswana. The passages are to be understood within two contexts, the source text culture and the receptor culture.

\section{Conclusion}

The translation of the term circumcision into the Setswana term of bogwera would have presented a Motswana reader with a cultural paradox. The translator, in translating the concept, thus not only performed an act of transmutation but also subverted the indigenous knowledge of the receptor culture. The translation of circumcision into bogwera is not only problematic on the basis of equivalence, or rather the lack thereof, but also on the basis of cultural signification. I argued that the translator could perhaps rather have used the word rupa as an equivalence for the word circumcision. The tensions between the two symbols permeate beyond the notion of equivalence, as it does not address the cultural, epistemic and religious links to these symbols. I have sought to argue that these tensions illustrate the epistemic privilege, othering and the colonial matrix of power embedded in the translation itself.

\section{Acknowledgements Competing interests}

The author declares that he has no financial or personal relationships that may have inappropriately influenced him in writing this article.

\section{Author's contributions}

I.D.M. is the sole author of this article.

\section{Ethical considerations}

This article followed all ethical standards for research without direct contact with human or animal subjects.

\section{Funding information}

This research received no specific grant from any funding agency in the public, commercial or not-for-profit sectors.

\section{Data availability}

Data sharing is not applicable to this article as no new data were created or analysed in this study.

\section{Disclaimer}

The views and opinions expressed in this article are those of the author and do not necessarily reflect the official policy or position of any affiliated agency of the author.

\section{References}

Bassnett, S. \& Trivedi, H. (eds.), 1999, Post-colonial translation: Theory and practice, Routledge, London.

Cohen, S.J.D., 2003, 'A brief history of Jewish circumcision blood', in E.W. Mark (ed.) The covenant of circumcision: New perspectives on an ancient Jewish Rite, pp. 30-43, Brandeis University Press, London.

Fanon, F., 1968, The wretched of the earth, Grove, New York, NY.

Karris, R.J., 1990, 'The Gospel according to Luke', in R.E. Brown, J.A. Fitzmyer \& R.E. Murphy (eds.), The new Jerome biblical commentary, pp. 675-721, PrenticeHall, Hoboken, NJ.

Marshall, I.H., 1978, The Gospel of Luke: A commentary on the Greek text, Paternoster Press, Milton Keynes.

Mgadla, P. \& Volz, S.C., 2006, Words of Batswana: Letters to Mahoka a Becwana 1883-1896, Translators/compilers, Van Riebeeck Society, Cape Town.

Moffat, R., 1842, Missionary labours and scenes in Southern Africa, J Snow, London.

Mothoagae, I.D., 2017, 'The transmutation of Bogwera in Luke 2:21 in the 1857 English-Setswana Bible', HTS Teologiese Studies/Theological Studies 73(3), 1-9. https://doi.org/10.4102/hts.v73i3.4523

Pao, W.D. \& Schnabel, J.E., 2007, 'Luke', in G.K. Beale \& D.A. Carson (eds.), Commentary on the New Testament use of the Old Testament, pp. 251-414, Baker Academic, Grand Rapids, MI.

Moffat, R. \& Moffat, M., 1951, Apprenticeship at Kuruman: Being the journals and the letters of Robert and Mary Moffat 1820-1828, I. Schapera (ed.), Chatto \& Windus, London.

Smith, E.W., 1925, Robert Moffat: One of God's gardeners, Edinburgh House, London.

Venuti, L., 1995, The translator's invisibility: A history of translation, Routledge, London. 